
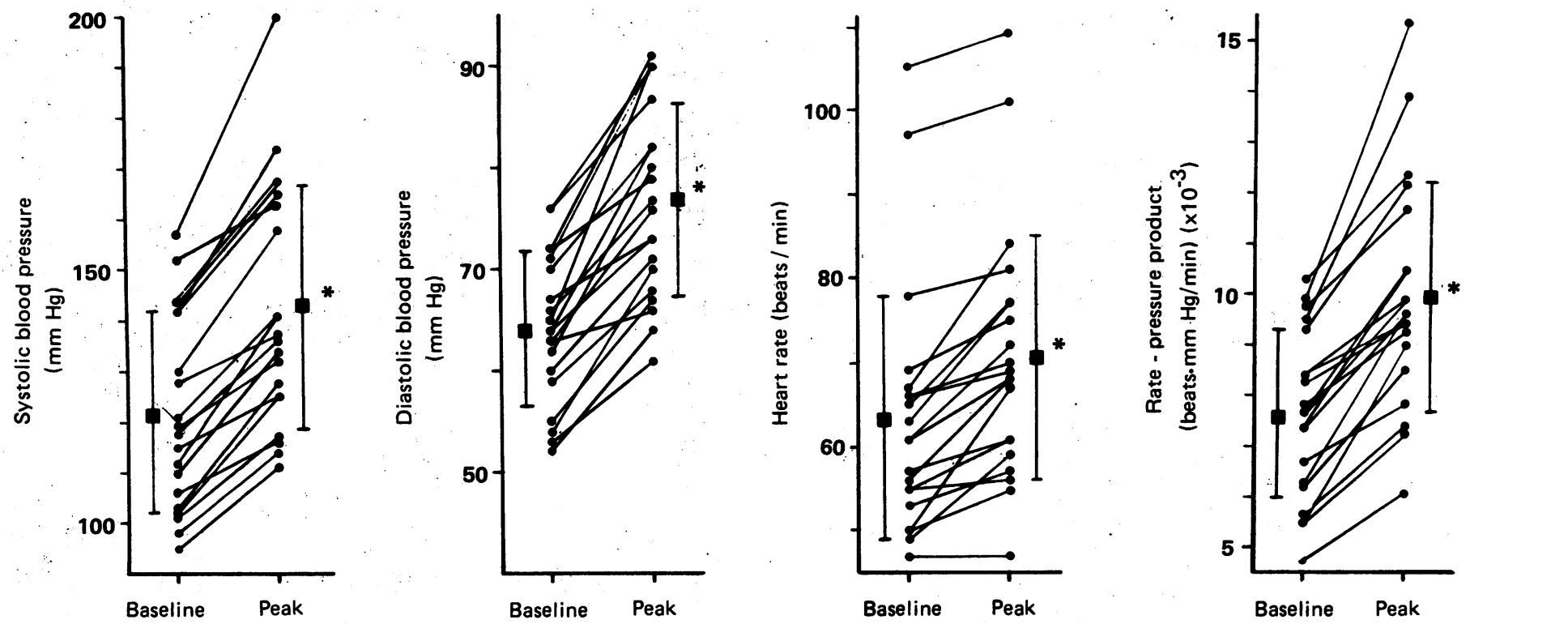

Effect of giving $200 \mu \mathrm{g}$ thyrotrophin releasing hormone intravenously on blood pressure, heart rate, and rate-pressure product in 20 patients. Vertical lines indicate means (SD).

${ }^{\star} \mathrm{p}<0.001$

concentrations are not found consistently, ${ }^{35}$ and increases in vascular resistance have been noted both before and after $\beta$ blockade. ${ }^{3}$ Nine of the patients were taking $\beta$ blockers, but their responses were similar to those of the other patients. Our study did not address the mechanism of the response, which did not seem to be affected by the vasoactive drugs being taken. Although useful in animals ${ }^{1}$ thyrotrophin releasing hormone has yet to be used therapeutically.

Though the thyrotrophin releasing hormone did not cause adverse effects in this study, it should be used cautiously in patients with uncontrolled angina or hypertension. The side effect of chest tightness reported previously ${ }^{4}$ may be due to myocardial ischaemia resulting from the rise in the rate-pressure product.

1 Holaday JW, D'Amato R, Faden AI. Thyrotrophin-releasing hormone improves cardiovascular function in experimental endotoxic and hemorrhagic shock. Science 1981;213:216-8.

2 Borowski GD, Garofano CD, Rose LI, Levy AL. Blood pressure response to thyrotropin-releasing hormone in euthyroid subjects. $\mathcal{f}$ Clin Endocrinol Metab 1984;58:197.

3 Zaloga GP, Chernow B, Zajtchuk R, Chin R, Rainey TG, Lake CR. Diagnostic dosages of protirelin (TRH) elevate BP by noncatecholamine mechanisms. Arch Interm Med 1984;144:1149.

4 Ormston BJ, Kilborn JR, Garry R, Amos J, Hall R. Further observations on the effect of synthetic thyrotrophin-releasing hormone in man. BrMed f 1971;ii:199-202.

5 Tuck M, Morley JE, Mayes D, et al. Thyrotropin releasing hormone (TRH) releases norepinephrine in man. Clin Res 1979;27:261A.

(Accepted 11 December 1986)

Departments of Cardiology and Nuclear Medicine, Guy's Hospital, London SE1 9RT

ERIC ROSENTHAL, MB, MRCP, registrar in cardiology

YOUSEF C NAJM, MB, BS, research fellow in cardiology

MICHAEL N MAISEY, MD, FRCP, professor of nuclear medicine

PAUL V L CURRY, MD, FRCP, consultant cardiologist

Correspondence to: Dr Rosenthal.

\section{Chlorpromazine induced fluid retention masquerading as idiopathic oedema}

An abnormality in dopaminergic tone has been implicated in the pathogenesis of idiopathic oedema. Chlorpromazine has antidopaminergic activity, and we describe a patient in whom chlorpromazine was reproducibly associated with severe fluid retention.

\section{Case report}

A 45 year old woman was investigated for severe, persistent oedema of two years' duration. She had a 25 year history of schizophrenia, and two years previously she had begun treatment with chlorpromazine hydrochloride $400 \mathrm{mg}$ daily. There was no history of organic disease.

Examination showed a woman $156 \mathrm{~cm}$ tall and weighing $70 \mathrm{~kg}$. Blood pressure was $120 / 80 \mathrm{~mm} \mathrm{Hg}$ and pulse $80 / \mathrm{min}$. Swelling of the face, breasts, and abdomen and pitting oedema of the ankles were evident. There was no other physical abnormality. Serum urea concentration was $3.8 \mathrm{mmol} / \mathrm{l}$, creatinine $102 \mathrm{mmol} / \mathrm{l}$, sodium $143 \mathrm{mmol} / \mathrm{l}$, total protein $70 \mathrm{~g} / \mathrm{l}$, and albumin $48 \mathrm{~g} / \mathrm{l}$. Results of urine analysis and an electrocardiogram and chest radiograph were all normal. Endocrine evaluation showed a free thyroxine concentration of $16.3 \mathrm{pmol} / \mathrm{l}$ and a thyroid stimulating hormone concentration of $2.0 \mathrm{mU} / 1 .:$ Resting plasma renin activity was $1.6 \mu \mathrm{g} / \mathrm{h} / \mathrm{l}$ and aldosterone concentration $4.58 \mathrm{nmol} / 1$ (mean control values (SD) $1.66(0.99)$ and $2.25(0.04)$, respectively). After the patient had been standing for two hours her plasma renin activity rose to $5.6 \mu \mathrm{g} / \mathrm{h} / \mathrm{l}$ and aldosterone concentration to $10.45 \mathrm{nmol} / 1$ (mean control values $5.81(3.30)$ and $6 \cdot 11(0 \cdot 09)$, respectively). Prolactin concentration was raised $(56 \mu \mathrm{g} / \mathrm{l})$.

She was treated with spironolactone $200 \mathrm{mg}$ daily but with no response. There was also no diuresis with kaluril (hydrochlorothiazide $50 \mathrm{mg}$ with amiloride $5 \mathrm{mg}$ ) and ethacrynic acid $50 \mathrm{mg}$ daily. The possibility of chlorpromazine induced alterations in dopaminergic tone was considered and she received bromocriptine $7.5 \mathrm{mg}$ daily for three months. No change was noted in body weight with this regimen. Chlorpromazine was then stopped. This was followed by a weight loss of $12 \mathrm{~kg}$ and the swelling resolved completely for the first time in two years. Six months later chlorpromazine was reintroduced because of an exacerbation of schizophrenia. She again gained weight $(15 \mathrm{~kg})$, accompanied by generalised swelling and facial bloating. The oedema dramatically resolved on withdrawal of the drug.

\section{Comment}

Peripheral oedema occurs in 1-3\% of patients taking phenothiazines and other psychotropic agents associated with prominent antidopaminergic activity. ${ }^{1}$ Dopaminergic neurones enhance renal sodium excretion by a direct effect on the renal tubule and by modulating renin and aldosterone secretion. ${ }^{2}$ Evidence exists that diminished dopaminergic tone may have a pathophysiological role in the fluid retention of idiopathic oedema. Kuchel et al found diminished urinary dopamine secretion in patients with idiopathic oedema. ${ }^{2}$ Norbiato et al reported an exaggerated rise in aldosterone concentrations in response to the dopamine antagonist metoclopramide in patients with idiopathic oedema. ${ }^{3}$ Sowers et al reported that patients with idiopathic oedema responded to the dopamine agonist bromocriptine with a diuresis. $^{4}$

By virtue of its antidopaminergic effects chlorpromazine may lead to fluid retention in patients so predisposed. The lack of response to bromocriptine in our patient while taking chlorpromazine may be accounted for by the antagonistic antidopaminergic effect of the phenothiazines. ${ }^{5}$

From all this evidence it is tempting to speculate that idiopathic oedema represents a range of varying degrees of fluid retention from overt oedema to a latent tendency for fluid retention (subclinical idiopathic oedema). Cryptic diminution of endogenous dopaminergic tone, further compromised by administration of antidopaminergic agents, might precipitate the appearance of clinically important oedema. Other undetermined factors working in concert with decreased dopaminergic tone may also play a part. 
Chlorpromazine and other psychotropic drugs with definite antidopaminergic properties should be considered among the possible causes of idiopathic oedema.

1 Baldessarini RJ. Drugs and the treatment of psychiatric disorders. In: Gillman AG, Goodman LS Gilman A, eds. The pharmacological basis of therapeutics. 6th ed. New York: Macmillan, 1980:397.

2 Kuchel O, Cuche JL, Buu NT, et al. Catecholamine excretion in "idiopathic" edema: decreased dopamine excretion, a pathogenic factor? 7 Clin Endocrinol Metab 1977;44:639-46.

3 Norbiato G, Bevilacqua M, Raggi P, et al. Effect of metoclopramide, a dopaminergic inhibitor, on renin and aldosterone in idiopathic edema: possible therapeutic approach with levodopa and carbidopa. $\mathcal{F}$ Clin Endocrinol Metab 1979;48:37-42.

4 Sowers R, Catania YP, Tuck M. Effects of bromocryptine on renin, aldosterone and prolactin responses to posture and metoclopramide in idiopathic edema: possible therapeutic approach. $f$ Clin Endocrinol Metab 1982;54:510-6.

5 Massino M, Giusippe D, Maria L, et al. Effects of different dopamine antagonists on bromocriptine induced inhibition of norepinephrine release. $f$ Clin Endocrinol Metab 1984;59:74-7.

(Accepted 6 fanuary 1987)

Endocrine Unit and Department Medicine C, Meir Hospital, Kfar Sava, and Sackler School of Medicine, Tel Aviv University, Tel Aviv, Israel

LIMA WITZ, MD, registrar in endocrinology

MENACHEM S SHAPIRO, MD, head of endocrine unit

LOUIS SHENKMAN, MD, head of department of medicine $C$

Correspondence to: Dr M S Shapiro, Meir Hospital, Kfar Sava, Israel.

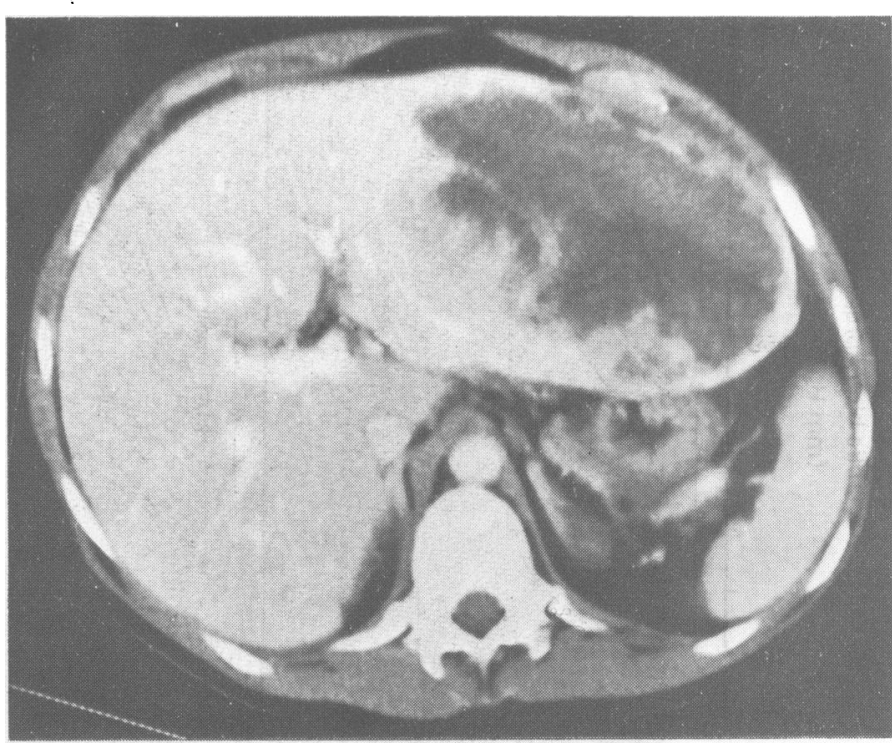

Abdominal computed tomogram in case 1 showing large tumour, with central necrosis and surrounding areas of haemorrhage, replacing most of left lobe of liver.

tomography showed several masses containing areas of calcification in both hepatic lobes, the appearances suggesting a multifocal liver tumour. Histological examination of a biopsy specimen showed hepatic adenoma but no malignancy.

She died three months later from a cardiac arrhythmia. Permission for necropsy. was refused.

\section{Comment}

This is the first report of hepatic adenomas developing during treatment with norethisterone alone. The women had received continuous high dose norethisterone for three and four years respectively, and in both, unusually, the adenomas were multiple. The risk of adenomas increases with duration of contraceptive treatment and high oestrogen dosage, ${ }^{12}$ but the effects of different doses of progestogen are not known. ${ }^{2}$

Both women had end stage renal failure requiring dialysis, and data on progestogen metabolism in such patients are few. ${ }^{4}$ As the drug is normally excreted in the urine, however, ${ }^{5}$ high concentrations of norethisterone and its conjugate metabolites may have accumulated in our patients. These cases show the need for caution in using norethisterone in patients with renal impairment, and modification of recommended doses may be necessary.

Hepatic adenomas may remain undiagnosed until quite $\operatorname{large}^{1}$ and may present suddenly with lifethreatening complications. Regular ultrasonography should lead to their early detection in patients at high risk.

We thank Professor G R Giles, University Department of Surgery, St James's Hospital, Leeds, and members of the department of radiology for their help in managing these patients, and also Mrs C Czenkusz for her help in preparing this article.

1 Edmondson HA, Henderson B, Benton B. Liver cell adenomas associated with the use of the oral contraceptive. N Engl f Med 1976;294:470-2.

Rooks JB, Ory AW, Ishak KG, et al. Epidemiology of hepatocellular adenoma. JAMA 1979;242:644-8.

3 Brander WL, Vosnides G, Ogg CS, West IE. Multiple hepatocellular tumours in a patient treated with oral contraceptives. Virchows Arch [Pathol Anat] 1976;370:69-76.

4 Emmanouel WS, Lindheimer MD, Katz AI. Metabolic and endocrine abnormalities in chronic renal failure. In: Brenner BM, Stein JH, eds. Chronic renal failure. New York: Churchill Livingstone, 1981:46-83.

5 Orme ML'E, Back WJ, Breckenridge AM. Clinical pharmacokinetics of oral contraceptive steroids. Clin Pharmacokinet 1983;8:95-136.

(Accepted 19 january 1987)

Renal Unit, General Infirmary at Leeds, Leeds LS1 3EX

P A KALRA, MA, MRCP, registrar

J A GUTHRIE, BA, MB, senior house officer

J B DIBBLE, MD, MRCP, senior registrar

J H TURNEY, MA, MRCP, consultant

A M BROWNJOHN, FRCP, consultant

Correspondence to: Dr Dibble.
A 23 year old woman had been treated by haemodialysis for two years. Heavy uterine bleeding had become debilitating, and after serious gynaecological disease had been excluded the bleeding was suppressed with norethisterone $10 \mathrm{mg}$ thrice

She presented three years later with fever, neutrophilia, erythrocyte sedimentation rate $155 \mathrm{~mm}$ in the first hour, and abnormal results of liver function tests. Abdominal ultrasonography showed multiple intrahepatic lucencies. Computed 